\title{
Pharmacognostical and Phytochemical Evaluation of Leaves of Mimusops elengi $\mathrm{L}$.
}

\author{
Vineeta Singh, V.N. Pandey, Kalawati Shukla \\ Experimental Botany and Nutraceutical Laboratory, Department of Botany, DDU Gorakhpur University, \\ Gorakhpur - 273009, (U.P.) India
}

\begin{abstract}
Herbal drug attaining wide acceptance day by day because they are safe, very effective and less costly. The utilization of plant as a medicine is mentioned in Ayurveda, Siddha, Unani medicines etc. but the therapeutic properties of most of them have not be proven scientifically. Therefore, Pharmacognostic and Phytochemical evaluation of Mimusops elengi $L$. is carried out to know the complete information of crude drug. Mimusops elengi L. (Sapotaceae) is an important medicinal plant because each and every part is used in treatment of various ailments. Boiled leaves are applied to head as a cold compress for headache and juice of the leaves squeezed into the eye for sore eye. In folk medicine infusion of bark is prescribed internally in disease of bladder and urethra. Unripe fruit is used as masticatory. It is therefore recommended to be chewed for fixing loose teeth. Powder of dried flower is a brain tonic and is useful as a snuff to treat Cephalalgia. So it is important to standardized the plant materials to be used as medicine. In this context the present work has been undertaken to examine the physiochemical and pharmacognostic evaluation of plant.
\end{abstract}

Keywords: Herbal drugs, Physiochemical, Pharmacological, Sapotaceae.

\section{Introduction}

Plants have always been the principal form of medicine in India and presently they are becoming popular throughout the world. The World health organization estimates that up to $80 \%$ of peoples still rely mainly on traditional medicine [1]. 40 species of Mimusops have been reported throughout world [2]. Mimusops elengi $\mathrm{L}$. is considered as one of the best medicinal plant because every parts of it is used in various way to cure a variety of human diseases.

In ayurveda the drug is mentioned as cooling cardiotonic, alexipharmic, stomachic, anthelmintic, astringent, cures biliousness, disease of gums and teeth [3]. In folk medicine bark infusion is prescribed internally in disease of bladder and urethra. Rinsing mouth with bark decoction is believed to strengthen the gums, reduce inflammation, and prevent bleeding of gums and stop bad breath caused by pyorrhea and dental caries. Decoction of bark is used to wash the wounds. Powder of dried flowers is a brain tonic and is useful as a snuff to treat cephalalgia. The flowers are also used as an expectorant, cures biliousness, liver complaints, diseases of the nose, headache. The smoke of the flower is used for treatment of asthma. The water distilled from the flowers is used as a stimulant medicine, calm anxiety, panic attacks and brain tonic $[4,5,6]$.

\subsection{Collection and Authentication of Plant}

\section{Materials And Methods}

Fresh leaves of Mimusops elengi L. were collected from the campus of DDU Gorakhpur University and authenticated by Herbarium Department of Botany, DDU Gorakhpur University Gorakhpur. The leaves were washed and dried under shade. The dried leaves were then pulverized with the help of mechanical grinder and kept in sealed jar at $4^{0} \mathrm{C}$ temperature in refrigerator.

\subsection{Preparation of Plant extract}

The dried leave powder was extracted with different Polar and Non Polar solvent (Methanol, Ethanol, Acetone, Chloroform, Water) using soxhlet apparatus (Fig. 1). After effective extraction solvent was concentrated using rotatory evaporator.

\subsection{Pharmacognostic Studies}

\subsubsection{Physiochemical evaluation}

The various physiochemical parameters such as total ash, acid insoluble ash, water soluble ash, extractive value and moisture content was determined as prescribed by Indian Pharmacopeia and WHO guideline.

\subsubsection{Fluorescence analysis}

Fluorescence analysis was carried out as per standard method described by Chase and Pratt (1949) [7], Kokoski (1958) [8] to determine the fluorescence properties of plant sample. 


\subsubsection{Organoleptic evaluation}

Organoleptic evaluation can be done by examine the color, odor, taste and texture as standard method by Wallis (1989) [9].

\subsubsection{Microscopic examination}

Microscopic study was carried by examine thin hand section under microscope

\subsubsection{Phytochemical Screening}

Phytochemical screening were carried using standard procedure described by Harborne (1973) [10], Trease and Evans (1989) and Sofowara (1993).

\section{Test for Alkaloids}

Mayer's Reagent ( $\mathrm{KI}+\mathrm{Hg}_{2} \mathrm{Cl}_{2}$ solutions): To the extract few drops of Mayer's reagent was added to produce cream colored precipitate which indicates the presence of alkaloids.

Dragondorff's reagent (excess of $\mathrm{KI}+\mathrm{BiNO} 3$ solutions): To the extract few drops of Dragondorff's reagent was added to produce reddish brown colored precipitate.

Hager's reagent (Picric acid): To the extract few drops of Hager's reagent was added to produce yellow colored precipitate which indicates the presence of alkaloids.

\section{Test for Glycosides}

Keller-Killiani Test: To the extract, $1 \mathrm{ml}$ of glacial acetic acid containing traces of ferric chloride and $1 \mathrm{ml}$ of concentrated sulphuric acid were added. A reddish brown colour formed at the junction of the 2 layers and the upper layer turned bluish green indicating the presence of glycosides.

Borntrager's Test: To the extract $1 \mathrm{ml}$ of benzene and $0.5 \mathrm{ml}$ of dilute ammonia solution were added to produced a reddish pink color which indicate the presence of glycosides.

\section{Test for Flavanoids}

Alkaline Reagent Test: To the extract few drops of $\mathrm{NaOH}$ solution were added. Formation of intense yellow color which disappeared upon addition of concentrated $\mathrm{HCl}$ indicated the presence of flavonoids.

\section{Test for Saponins}

Foam Test: To the extract $2 \mathrm{ml}$ of distilled water was added and shaken vigorously for 15 minutes. If foam produced persists for ten minutes it indicates the presence of saponins.

\section{Test for Tanins and Phenols}

Ferric Chloride Test: To the extract $1 \mathrm{ml}$ of ferric chloride solution was added. Appearance of bluish-black colour confirmed the presence of tannins.

\section{Test for Steroids and Terpeneoids}

Liebermann Burchard Test: To the extract $1 \mathrm{ml}$ of anhydrous acetic acid and $1 \mathrm{ml}$ chloroform was added and cooled at $0^{\circ} \mathrm{C}$. Then 1 drop of concentrated sulphuric acid was added from the side of the test tube. A brown ring form at the junction of two layers. The upper layer turns green which show the presence of steroids and formation of deep red color indicates the presences of terpenoids.

Salkowski Test: To the extract $1 \mathrm{ml}$ of chloroform and $1 \mathrm{ml}$ of sulphuric acid was added. Yellow color upper layer indicate the presence of terpenoids while reddish brown color lower layer showed the presence of steroids.

\section{Test for Proteins}

Biuret Test: To the extract, $1 \mathrm{ml}$ of $40 \% \mathrm{NaOH}$ solution and two drops of one percent $\mathrm{CuSO}_{4}$ solution were added. Violet color appears indicates the presence of proteins.

Ninhydrin test: Two drops of ninhydrin solution (10 mg of ninhydrin in $200 \mathrm{ml}$ of acetone) are added to $2 \mathrm{ml}$ of aqueous filtrate. Appearance of purple colour indicate the presence of amino acids.

\section{Test for Carbohydrate}

Fehling's Test: To the extract, Fehling's solution was added and boiled in water bath. Brick red precipitate indicated the presence of carbohydrates

Benedict's reagent: To the extract, Benedict's solution was added and boiled in water bath. Formation of a red precipitate showed the presence of carbohydrates.

\section{Result}

The result revealed that the qualitative analysis of phytochemical showed the presence of saponin, glycosides, flavanoids, steroids, terpenoids, tanins, phenols, carbohydrates, protein and amino acid while alkaloids was absent in the extract (Table 1). The percentage yield of the methanol extract was higher $17.84 \pm$ 
0.57 compared to ethanol $24.85 \pm 2.23$, chloroform $13.42 \pm 0.63$, acetone $6.97 \pm 0.25$ and aqueous extract (Table2 and Fig. 2). The physiochemical analysis showed that the total ash was $5.43 \pm 0.02$, acid insoluble ash $1.15 \pm 0.24$, and water soluble ash 3.6 \pm 0.79 . The moisture content of crude drug was found to be $4.7 \pm 0.6$ while the swelling index was $15.4 \pm 0.25$ and foaming index was not more than 100 (Table 3 ). The result of fluorescence analysis and organoleptic evaluation were shown in Table $4 \& 5$ respectively. T ransverse section of leaves through midribs shows the presence of upper and lower epidermis covered by a thick layer cuticle. The stomata are of anomocytic type. The mesophyll cells are differentiated into palisade and spongy parenchyma. Below the epidermis radially elongated palisades tissues are present which is followed by spongy parenchyma. The vascular bundles are present in the midrib region (Fig. 3).Transverse section of petiole is almost circular in outline. Single layer of epidermis composed of oval cells covered by a thick cuticle layer. Epidermis is followed by hypodermis which is followed by wide zone of cortex. The vascular bundles are situated in the centre (Fig. 4).

Table 1: Preliminary Phytochemical Screening ofMimusops elengi L. leaves

\begin{tabular}{|c|c|c|c|c|c|c|c|}
\hline \multirow[t]{2}{*}{ Chemical constituent } & \multirow[t]{2}{*}{ Tests } & \multirow[t]{2}{*}{ Colour } & \multicolumn{5}{|c|}{ Extracts } \\
\hline & & & MLE & ELE & CLE & ALE & $\mathbf{A q E}$ \\
\hline \multirow{3}{*}{ Alkaloids } & Mayer's & Cream & \multirow{3}{*}{-} & \multirow{3}{*}{-} & \multirow{3}{*}{-} & \multirow{3}{*}{ - } & \multirow{3}{*}{-} \\
\hline & Hager's & Reddish brown & & & & & \\
\hline & Wagner's & Reddish brown & & & & & \\
\hline Saponins & Foam & Yellow & ++ & +++ & + & + & +++ \\
\hline \multirow[t]{2}{*}{ Glycosides } & Keller-killiani & Reddish brown & - & ++ & ++ & - & +++ \\
\hline & Borntragers & Reddish pink & - & +++ & +++ & - & +++ \\
\hline Flavanoids & Alkaline & Yellow & +++ & +++ & +++ & +++ & +++ \\
\hline \multirow[t]{2}{*}{ Steroids /Terpeniods } & $\begin{array}{l}\text { Libermann- } \\
\text { Burchard }\end{array}$ & Green/Red & +++ & +++ & +++ & +++ & +++ \\
\hline & Salkowski test & Red/Yellow & +++ & +++ & +++ & +++ & +++ \\
\hline Tanins\&Phenols & Ferric chloride & Blue black & +++ & +++ & +++ & - & +++ \\
\hline \multirow[t]{2}{*}{ Carbohydrates } & Benedict's & Red precipitate & ++ & ++ & ++ & ++ & ++ \\
\hline & Fehling's test & Brick red & ++ & ++ & ++ & ++ & ++ \\
\hline \multirow{2}{*}{$\begin{array}{l}\text { Proteins and amino } \\
\text { acids }\end{array}$} & Ninhydrin test & Violet color & + & + & + & + & + \\
\hline & Biuret test & Purple & + & + & + & + & + \\
\hline
\end{tabular}

MLE-Methanol leaf extract, ELE- Ethanol leaf extract, CLE- Chloroform leaf extract, ALE- Acetone leaf extract, AqE- Aqueous leaf extract

Table 2: Percentage Yield of different extract of Mimusops elengi L. leaves

\begin{tabular}{|c|c|}
\hline Solvents & Leaves \\
\hline Methanol & $46.32 \pm 1.05$ \\
\hline Ethanol & $32.29 \pm 1.42$ \\
\hline Chloroform & $60.70 \pm 1.38$ \\
\hline Acetone & $22.25 \pm 1.48$ \\
\hline Aqueous & $22.17 \pm 1.76$ \\
\hline Ethyl Acetate & $8.19 \pm 1.43$ \\
\hline Ethanol 80\% & $50.95 \pm 1.73$ \\
\hline Methanol 80\% & $41.82 \pm 1.15$ \\
\hline
\end{tabular}

Table 3: Physiochemical parameters of Mimusops elengi L. leaves

\begin{tabular}{|l|l|}
\hline Ash content & Values \\
\hline Total ash & $5.43 \pm 0.02$ \\
\hline Acid insoluble ash & $1.15 \pm 0.24$ \\
\hline Water soluble ash & $3.6 \pm 0.79$ \\
\hline Moisture content & $4.7 \pm 0.6$ \\
\hline Foaming index & More than 1000 \\
\hline Swelling index & $15.4 \pm 0.25$ \\
\hline
\end{tabular}

Table 4: Organoleptic characters of Mimusops elengi L. leaves

\begin{tabular}{|c|l|l|l|l|}
\hline Solvents & Color & Taste & Consistency & Odor \\
\hline Methanol & Dark green & Bitter & Semi Solid & Characteristic \\
\hline Ethanol & Green & Bitter & Semi Solid & Characteristic \\
\hline Chloroform & Olive green & Sweet & Solid & Characteristic \\
\hline Acetone & Leafy green & Sweet & Semi Solid & Characteristic \\
\hline Aqueous & Mustard yellow & Slight bitter & Semi Solid & Fruity \\
\hline
\end{tabular}

Table 5: Fluorescence analysis of leaves powder ofMimusopselengiL.

\begin{tabular}{|l|l|l|}
\hline Powder Treatment & Oridnary light & UV light \\
\hline Powder & Olive Green & Brown \\
\hline Powder + concHCl 50\% & Green & Brown \\
\hline
\end{tabular}


Pharmacognostical and Phytochemical Evaluation of Leaves of Mimusops elengi $L$.

\begin{tabular}{|l|l|l|}
\hline Powder + concHCl & Dark green & Brown \\
\hline Powder + conc $\mathrm{HNO}_{3}$ & Brown & Red \\
\hline Powder + conc $\mathrm{HNO}_{3} 50 \%$ & Leafy green & Purple \\
\hline Powder + conc $\mathrm{H}_{2} \mathrm{SO}_{4} 50 \%$ & Olive green & Brick red \\
\hline Powder + conc $\mathrm{H}_{2} \mathrm{SO}_{4}$ & Brown & Green \\
\hline Powder $+1 \mathrm{~N} \mathrm{NaOH} \mathrm{in} \mathrm{H}_{2} 0$ & Leafy green & Brown \\
\hline Powder $+1 \mathrm{NNaOH}$ in methanol & Green & Red \\
\hline Powder $+5 \% \mathrm{FeCl}_{3}$ & Black & Purple \\
\hline Powder + glacial acetic acid & Leafy green & Blood red \\
\hline Powder + benzene & Olive green & Pink \\
\hline Powder $+\mathrm{NH}_{3}$ & Dark green & Brown \\
\hline Powder + choroform & Olive Green & Pink \\
\hline Powder + methanol & Olive Green & Pink \\
\hline Powder +ethanol & Olive Green & Red \\
\hline
\end{tabular}
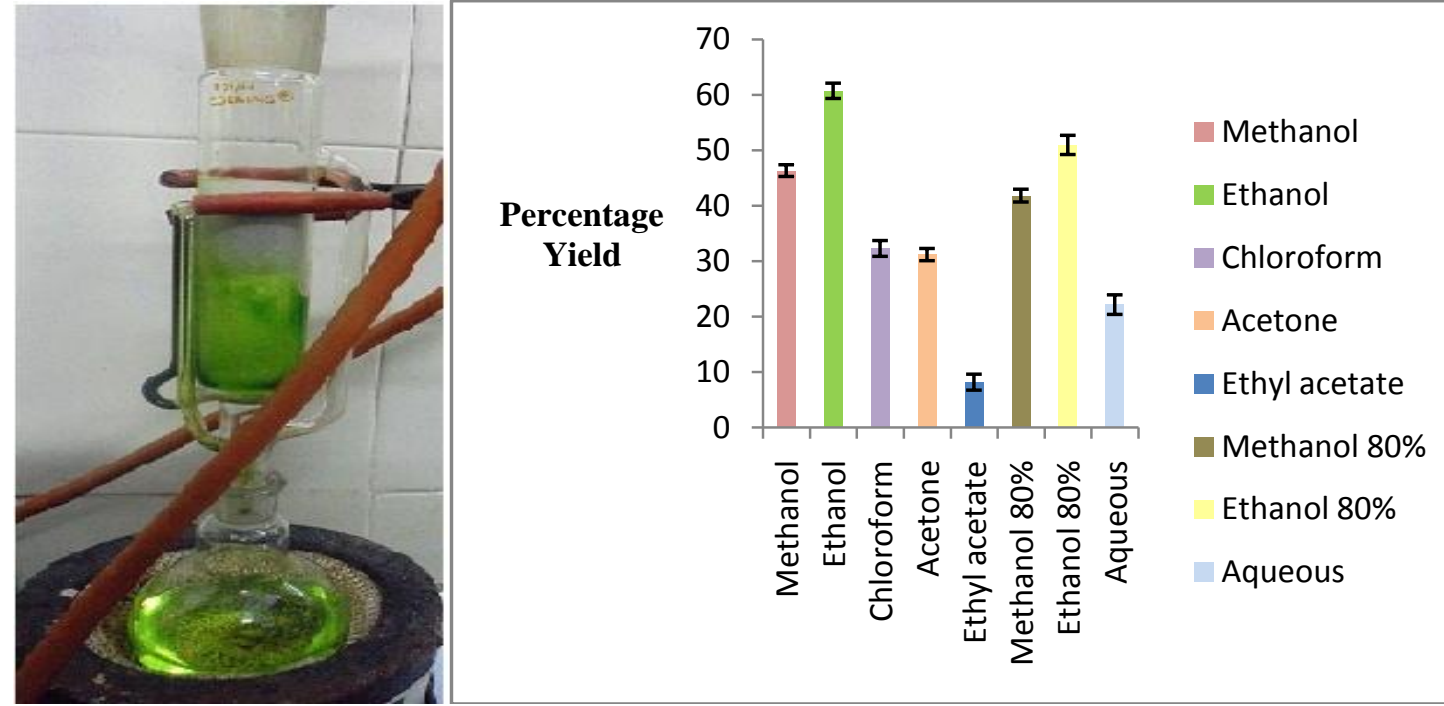

Fig 1: Extraction through Soxhelet Fig 2: Percentage yield of different extract of leaf

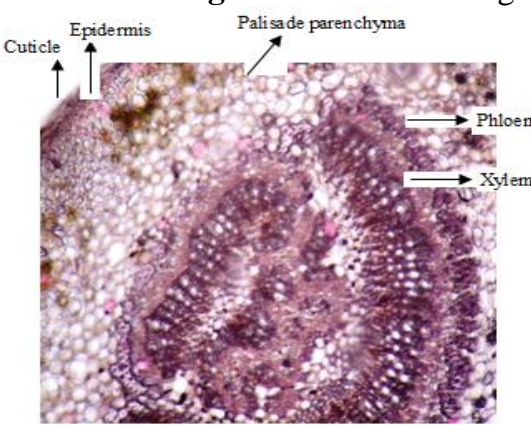

Fig.3: T.S. of Leaf

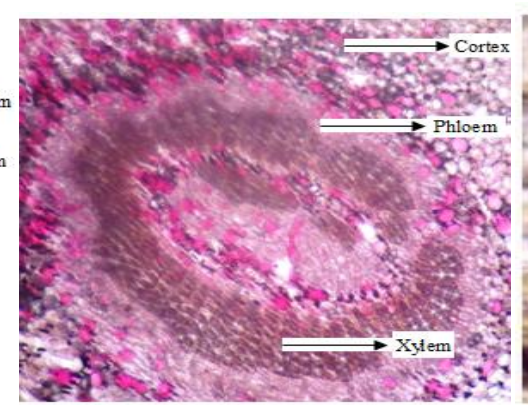

Fig. 4: T.S. of Stem

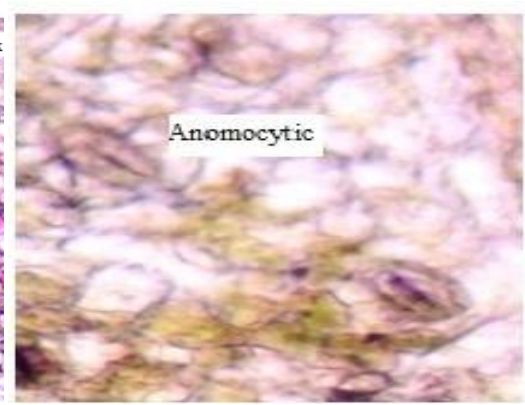

Fig. 5: Adaxial Surface of Leaf

\section{Discussion}

The trust of people in the natural products of plant has made the use of plant an indispensable part in medicine. In recent years medicinal plants has been found to play a vital role in preparation of new and improved medicine. One of the most important aspects for the utilization of plant derived drug is to determine its microscopic, macroscopic, physicochemical, organoleptic and phytochemical parameters. These parameters are helpful for identifying purity and quality of crude drugs. Therefore the present study was undertaken to reveal the pharmacognostical and phytochemical parameters so it can be used for the profiling of drug as well as future monograph development and preparation of new herbal formulation.

\section{Acknowledgement}

Authors are thankful to the Head, Department of Botany, DDU Gorakhpur University, Gorakhpur for providing necessary facilities.

Funding: This research did not receive any specific grant.

\section{References}


[1] Fransworth NR., AkereleOlayiwola, Bingel AS, Soejarto DD, Guo Z. Medicinal plant in therapy. Bulletin of the WHO, 1985; 63(6): 965-981.

[2] Chopra RN., Nayar SL., Chopra IC.Glossary of Indian Medicinal plants. CSIR, New Delhi, $1956 ; 169$.

[3] Chopra RN, Nayar SL, Chopra IC, Handa KL, Kapoor LD. Indigenous drug of India. UN Dhur and Sons. Ltd. Calcutta, $1958 ; 514$.

[4] Dymock W, Warden CJ, Hooper D. Pharmacographia indica, vol I, Thacker, spink and co, Calcutta, 1891.

[5] Nadkarni, AK. Dr. K.M. Nadkarni's India MateriaMedica $3^{\text {rd }}$ edn. Popular Book Depot Bombay, $1954 ; 800-802$.

[6] Mitra R. Bakula-A reputed drugs of Ayurveda, its History, uses in Indian medicine. Indian Journ. Hist. Sci. 1981; 16(2): 169-180.

[7] Chase CR, Pratt RS. Fluorescence of powdered vegetables drugs with particular reference to development of a system of identification. Journal of American Pharmacology Association, 1949; 38: 324-333

[8] Kokoshi CJ, Kokoshi RJ, Sharma FJ. Fluorescence of powdered vegetable drugs under ultraviolet radiation. Journal of Pharmaceutical Asses. 1958; 47: 75-77.

[9] Wallis TE. Text book of Pharmacognosy, London: Bailliere Tindall, 1989; 530

[10] Harborne JB, Phytochemical Methods In: A guide to modern techniques of plant analysis. $3^{\text {rd }}$ Ed. Chapman and Hall company, U.K. ICMR, 1998, pp.56-99.

[11] Trease GE, Evans WC. Pharmacognosy (11 ${ }^{\text {th }}$ Edn), BrailliarTiridal Canadian. Mac million publisher. 119-115.

[12] Sofowara A, Medicinal Plants and Traditional Medicine in Africa, Spectrum Book Ltd. 1993; 289.

[13] Anonymous. Indian Pharmacopeia, Indian Pharmacopeia Commission, Govt. of India, New Delhi. 1996; 53-54.

IOSR Journal of Pharmacy and Biological Sciences (IOSR-JPBS) is UGC approved Journal with S1. No. 5012, Journal no. 49063.

Vineeta Singh. "Pharmacognostical and Phytochemical Evaluation of Leaves of Mimusops elengi L." IOSR Journal of Pharmacy and Biological Sciences (IOSR-JPBS) 12.4 (2017): 45-49. 